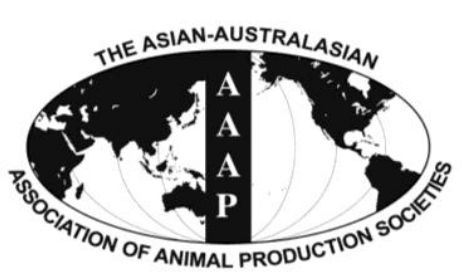

Open Access

Asian Australas. J. Anim. Sci.

Vol. 27, No. 7 : 965-973 July 2014

http://dx.doi.org/10.5713/ajas.2013.13416

www.ajas.info

pISSN 1011-2367 elSSN 1976-5517

\title{
Effects of a Chelated Copper as Growth Promoter on Performance and Carcass Traits in Pigs
}

\author{
J. Zhao*, G. Allee ${ }^{1}$, G. Gerlemann ${ }^{1}$, L. Ma ${ }^{1}$, M. I. Gracia ${ }^{2}$, D. Parker, \\ M. Vazquez-Anon, and R. J. Harrell ${ }^{3}$ \\ Novus International Inc, Saint Charles, MO, USA 63304
}

\begin{abstract}
Three studies were conducted to investigate whether a chelated $\mathrm{Cu}$ can replace $\mathrm{CuSO}_{4}$ as a growth promoter in pigs. In Exp. 1, a total of 240 piglets (Large White $\times$ Landrace, $7.36 \pm 0.10 \mathrm{~kg}$ ) were randomly allocated to 1 of 3 treatments with 8 replicates and 10 piglets per pen. Treatments included a NRC control $\left(\mathrm{CuSO}_{4}, 6 \mathrm{mg} / \mathrm{kg}\right)$, two $\mathrm{Cu}$ supplementations from either $\mathrm{CuSO}_{4}$ or $\mathrm{Cu}(\mathrm{HMTBa})_{2}$ at $170 \mathrm{mg} / \mathrm{kg}$. Pigs fed $\mathrm{Cu}(\mathrm{HMTBa})_{2}$ were $6.0 \%$ heavier than pigs fed either the NRC control or $170 \mathrm{mg} / \mathrm{kg} \mathrm{CuSO}_{4}(\mathrm{p}=0.03)$ at the end of the experiment. During the 42 days of experimental period, pigs fed $\mathrm{Cu}(\mathrm{HMTBa})_{2}$ gained $9.0 \%$ more $(\mathrm{p}=0.01)$, tended to eat more feed $(\mathrm{p}=0.09)$, and had better feed efficiency $(\mathrm{p}=0.06)$ than those fed $\mathrm{CuSO}_{4}$. Compared with the $6 \mathrm{mg} / \mathrm{kg} \mathrm{CuSO}{ }_{4} \mathrm{NRC}$ control, liver $\mathrm{Cu}$ was increased 2.7 times with $170 \mathrm{mg} / \mathrm{kg} \mathrm{CuSO}{ }_{4}$ supplementation, and was further increased with $\mathrm{Cu}(\mathrm{HMTBa})_{2}(4.5$ times, $\mathrm{p}<0.05)$. In Exp. 2, a total of 616 crossbred piglets (PIC, $5.01 \pm 0.25 \mathrm{~kg}$ ) were randomly allocated to 1 of 4 treatments with 7 replicates and 22 piglets per pen. Treatments included a NRC control (from $\left.\mathrm{CuSO}_{4}\right)$, and three pharmaceutical levels of $\mathrm{Cu}(150 \mathrm{mg} / \mathrm{kg}$ ) supplemented either from $\mathrm{CuSO}_{4}$, tri-basic copper chloride $\left(\mathrm{Cu}_{2}[\mathrm{OH}]_{3} \mathrm{Cl}\right)$, or $\mathrm{Cu}(\mathrm{HMTBa})_{2}$. Pigs fed $\mathrm{CuSO}_{4}$ or $\mathrm{Cu}(\mathrm{HMTBa})_{2}$ had better feed efficiency $(\mathrm{p}=0.01)$ and tended to gain more $(\mathrm{p}=0.08)$ compared with those fed the NRC control. Pigs fed $\mathrm{Cu}_{2}(\mathrm{OH})_{3} \mathrm{Cl}$ were intermediate. Pigs fed $\mathrm{Cu}(\mathrm{HMTBa})_{2}$ had the highest liver $\mathrm{Cu}$, which was significantly higher than those fed $\left(\mathrm{Cu}_{2}[\mathrm{OH}]_{3} \mathrm{Cl}\right)$ or the negative control $(\mathrm{p}=$ 0.01). In Exp. 3, a total of 1,048 pigs (PIC, $32.36 \pm 0.29 \mathrm{~kg}$ ) were allotted to 6 treatments with 8 replicates per treatment and 20 to 22 pigs per pen. The treatments included a NRC control with $4 \mathrm{mg} / \mathrm{kg} \mathrm{Cu}$ from $\mathrm{CuSO}_{4}$, a positive control with $160 \mathrm{mg} / \mathrm{kg} \mathrm{Cu}$ from CuSO${ }_{4}$, and incremental levels of $\mathrm{Cu}(\mathrm{HMTBa})_{2}$ at 20, 40, 80, and $160 \mathrm{mg} / \mathrm{kg}$. During the overall experimental period of 100 days, no benefit from $160 \mathrm{mg} / \mathrm{kg} \mathrm{CuSO}_{4}$ was observed. Pigs fed $\mathrm{Cu}(\mathrm{HMTBa})_{2}$ had increased ADG (linear and quadratic, $\mathrm{p} \leq 0.05$ ) and feed efficiency (linear and quadratic, $\mathrm{p} \leq 0.05$ ) up to $80 \mathrm{mg} / \mathrm{kg}$ and no further improvement was observed at $160 \mathrm{mg} / \mathrm{kg}$ for the whole experimental period. Pigs fed $80 \mathrm{mg} / \mathrm{kg} \mathrm{Cu}(\mathrm{HMTBa})_{2}$ weighed $1.8 \mathrm{~kg}$ more $(\mathrm{p}=0.07)$ and were $2.3 \mathrm{~kg}$ heavier in carcass $(\mathrm{p}<0.01)$ compared with pigs fed 160 $\mathrm{mg} / \mathrm{kg} \mathrm{CuSO} \mathrm{S}_{4}$. In addition, loin depth was increased with increased $\mathrm{Cu}(\mathrm{HMTBa})_{2}$ supplementation with pigs fed $80 \mathrm{mg} / \mathrm{kg} \mathrm{Cu}(\mathrm{HMTBa})_{2}$ had the greatest loin depth $(\mathrm{p}<0.05)$. In summary, $\mathrm{Cu}(\mathrm{HMTBa})_{2}$ can be used to replace high $\mathrm{CuSO}_{4}$ as a growth promoter in nursery and grower-finisher pigs. (Key Words: Chelated Trace Mineral, $\mathrm{Cu}(\mathrm{HMTBa})_{2}$, Copper, Growth Promoter, Swine)
\end{abstract}

\section{INTRODUCTION}

Requirement of $\mathrm{Cu}$ as a nutrient is low and NRC (1998) recommends 3 to $6 \mathrm{mg} / \mathrm{kg} \mathrm{Cu}$ for nursery and grower-

\footnotetext{
* Corresponding Author: Junmei Zhao. 20 Research Park Dr., Saint Charles, MO USA 63304. Tel: +1-314-8257211, E-mail: zhaojunmei@hotmail.com

${ }^{1}$ University of Missouri, Columbia, MO, USA 65211.

${ }^{2}$ Imasde Agroalimentaria, Madrid, Spain 28224.

${ }^{3}$ Carthage Veterinary Service, Carthage, IL USA 62321.

Submitted Jul. 13, 2013; Revised Sept. 25, 2013; Accepted Nov. 27, 2013
}

finisher pigs. In practice, pharmaceutical $\mathrm{Cu}$ from $\mathrm{CuSO}_{4}$ $(125$ to $250 \mathrm{mg} / \mathrm{kg}$ ) is routinely added in nursery pigs as a growth promoter and its benefits on feed intake and weight gain have been well documented (Bunch et al., 1961; Hawbaker et al., 1961). However, high dietary $\mathrm{Cu}$ presents an environmental concern when excess $\mathrm{Cu}$ is excreted in feces (Kornegay and Harper, 1997). Roof and Mahan (1982) reported a 14-fold increase of fecal $\mathrm{Cu}$ excretion with $250 \mathrm{mg} / \mathrm{kg} \mathrm{CuSO}{ }_{4}$ supplementation compared with the non-supplemented control. Accumulation of $\mathrm{Cu}$ and $\mathrm{Zn}$ in the soil has been implicated to reduce crop yield (Tucker, 
1997) and pose an environmental threat. In addition, it has been demonstrated that high dietary $\mathrm{Cu}$ from inorganic sources antagonizes other nutrients utilization, such as $\mathrm{Zn}$ (Zhao et al., 2008) and P (Banks et al., 2004). Due to the negative impact of high dietary $\mathrm{CuSO}_{4}$, the Commission of the European Communities regulate maximum allowed total $\mathrm{Cu}$ in feed with $170 \mathrm{mg} / \mathrm{kg}$ in piglets up to 12 weeks of age and $25 \mathrm{mg} / \mathrm{kg}$ in all other pigs. Other countries are following with similar regulations.

The mode of action of high $\mathrm{Cu}$ might due to its antibacterial function in the lumen (Shurson et al., 1990) directly or indirectly through absorption from lumen to liver, secretion to the bile, and then back to the lumen loop. This theory is partially supported by Zhou et al. (1994), whose research indicated that intravenous injection of copper histidinate, which bypass the lumen, had similar growth promoting effect as dietary supplementation. Compared with inorganic trace minerals, chelated trace minerals are more bioavailable, likely due to reduced incidence of antagonism with other dietary constituents in the gastrointestinal tract (Wang et al., 2007; Zhao et al., 2010). Our previous study suggested that $\mathrm{Cu}(\mathrm{HMTBa})_{2}$ is better at avoiding nutrient antagonism and less is needed to achieve similar or better performance compared with inorganic minerals in broilers (Zhao et al., 2010) and nursery pigs (Zhao et al., 2009). The objective of these studies was to evaluate a chelated $\mathrm{Cu}\left(\mathrm{Cu}[\mathrm{HMTBa}]_{2}\right)$ as a growth promoter on performance, liver $\mathrm{Cu}$ and carcass traits in nursery and grower-finisher pigs.

\section{MATERIALS AND METHODS}

Exp. 1 was conducted in Segovia, Spain and met appropriate current quality standards and guidance of the European Food Safety Authority (EFSA). Exp. 2 and 3 were conducted at the University of Missouri (Columbia, MO). All animal procedures were approved by the University of Missouri Animal Care and Use Committee. Cu(HMTBa $)_{2}$ (Mintrex $\mathrm{Cu}$, Novus International Inc., St Charles, $\mathrm{MO}$ ) is a chelate of one $\mathrm{Cu}$ atom coordinated with two molecules of 2-hydroxy-4-methylthio butanoic acid (HMTBa). Methionine activity from $\mathrm{Cu}(\mathrm{HMTBa})_{2}(80 \%$ Met activity,
Yi et al., 2007) was accounted for and all diets were adjusted to be equal in methionine. Tribasic $\mathrm{Cu}$ chloride $\left(\mathrm{Cu}_{2}[\mathrm{OH}]_{3} \mathrm{Cl}\right)$ is a more concentrated form of $\mathrm{Cu}(58 \%)$, less soluble in water $(<1 \%)$, and is viewed as a less destructive form of $\mathrm{Cu}$ when combined with vitamins.

\section{Exp. 1: Benefits of $\mathrm{Cu}(\mathrm{HMTBa})_{2}$ as a growth promoter in nursery pigs}

A total of 240 crossbred piglets (Large WhitexLandrace, $26 \mathrm{~d}$ of age, $7.36 \pm 0.10 \mathrm{~kg}$ ) were randomly allocated to 1 of 3 experimental treatments based on sex, litter of origin, and BW with 8 replicates for each treatment and 10 piglets per pen. All pigs were fed a common creep feed from 21 to 25 days of age, then initiated treatments at 26 days of age. The treatments included a NRC control $(\mathrm{Cu} 6 \mathrm{mg} / \mathrm{kg}$, Mn 4 $\mathrm{mg} / \mathrm{kg}$, and $\mathrm{Zn} 100 \mathrm{mg} / \mathrm{kg}$ for phase I; Cu $5 \mathrm{mg} / \mathrm{kg}$, Mn 3 $\mathrm{mg} / \mathrm{kg}$, and Zn $80 \mathrm{mg} / \mathrm{kg}$ for phase II from sulfates), as well as the two treatments at European maximum level (total $\mathrm{Cu}$ $170 \mathrm{mg} / \mathrm{kg}, \mathrm{Mn}$ and $\mathrm{Zn}$ at $150 \mathrm{mg} / \mathrm{kg}$ from sulfates) with added $\mathrm{Cu}$ came either from $\mathrm{CuSO}_{4}$ or $\mathrm{Cu}(\mathrm{HMTBa})_{2}$. Table 1 listed detailed treatment descriptions. The nursery rooms were lit by a combination of daylight (through skylights) and artificial light (non-programmable). The pens were slatted and ventilation was achieved by single, variablespeed fans linked to temperature sensors. Diets were provided ad libitum throughout the trial from hoppers and water from two nipple drinkers per pen.

Typical European mixed-grain diets (barley, wheat, corn, and soybean meal) were formulated to meet or exceed NRC (1998) nutrient recommendation for piglets (Table 2). Pigs were fed two phase diets (d 0 to 14 and d 15 to 42). No veterinary antibiotics or veterinary zinc oxide was included in any diets. Diets were analyzed for $\mathrm{Cu}$ content using atomic absorption spectrometry (AOAC 968.08), ash by incineration (AOAC 942.05), protein by Kjeldahl (AOAC 984.13), and ether extract by Soxhlet fat analysis (AOAC 920.39) as described by the AOAC (2000). Weight gains, feed intakes and feed conversion were determined at the end of each feeding period. At the end of the experiment, one medium-size piglet per pen was slaughtered and tissue sampled (muscle, liver, kidney, skin and fat, and tibia bone)

Table 1. Treatment description (Exp. 1) ${ }^{1}$

\begin{tabular}{|c|c|c|c|}
\hline Trt & & Phase I (d 0 to 14$)$ & Phase II (d 15 to 42$)$ \\
\hline 1 & $\mathrm{NRC}$ control $\left(\mathrm{CuSO}_{4}\right.$ at $\left.6 \mathrm{mg} / \mathrm{kg}\right)$ & $\begin{array}{l}\mathrm{Cu} 6 \mathrm{mg} / \mathrm{kg}, \mathrm{Mn} 4 \mathrm{mg} / \mathrm{kg}, \mathrm{Zn} 100 \mathrm{mg} / \mathrm{kg} \text { from } \\
\text { sulfates }\end{array}$ & $\begin{array}{l}\mathrm{Cu} 5 \mathrm{mg} / \mathrm{kg}, \mathrm{Mn} 3 \mathrm{mg} / \mathrm{kg}, \mathrm{Zn} 80 \\
\mathrm{mg} / \mathrm{kg} \text { from sulfates }\end{array}$ \\
\hline 2 & $\mathrm{CuSO}_{4}$ at $170 \mathrm{mg} / \mathrm{kg}$ & $\begin{array}{l}\mathrm{Cu} 170 \mathrm{mg} / \mathrm{kg}, \mathrm{Mn} 150 \mathrm{mg} / \mathrm{kg}, \mathrm{Zn} 150 \mathrm{mg} / \mathrm{kg} \\
\text { from sulfates }\end{array}$ & Same as phase I \\
\hline 3 & $\mathrm{Cu}(\mathrm{HMTBa})_{2}$ at $170 \mathrm{mg} / \mathrm{kg}^{2}$ & $\begin{array}{l}\mathrm{Cu}(\mathrm{HMTBa})_{2} 170 \mathrm{mg} / \mathrm{kg}, \quad \mathrm{Mn} 150 \mathrm{mg} / \mathrm{kg}, \mathrm{Zn} \\
150 \mathrm{mg} / \mathrm{kg} \text { from sulfates }\end{array}$ & Same as phase I \\
\hline
\end{tabular}

\footnotetext{
Analyzed $\mathrm{Cu}$ using atomic absorption spectrometry: 15,149 , and $169 \mathrm{mg} / \mathrm{kg}$ for treatment 1 to 3 in phase I, and 11,145 , and $160 \mathrm{mg} / \mathrm{kg}$ in phase II, respectively.

${ }^{2}$ Chelate of one $\mathrm{Cu}$ atom coordinated with 2 molecules of 2-hydroxy-4-methylthio butanoic acid (HMTBa).
} 
Table 2. Basal diet composition and nutrient profile (Exp. 1)

\begin{tabular}{|c|c|c|}
\hline Ingredients (\%) & $\begin{array}{l}\text { Phase I } \\
\text { (d } 0 \text { to } 14 \text { ) }\end{array}$ & $\begin{array}{l}\text { Phase II } \\
\text { (d } 15 \text { to } 42 \text { ) }\end{array}$ \\
\hline Barley & 9.70 & 37.00 \\
\hline Cooked wheat & 30.25 & - \\
\hline Wheat & - & 4.22 \\
\hline Cooked corn & 16.50 & - \\
\hline Corn & - & 27.35 \\
\hline Extruded soybean & 15.78 & 8.00 \\
\hline Soybean meal & - & 11.90 \\
\hline Dried whey & 11.70 & - \\
\hline Soy protein & 12.00 & 5.00 \\
\hline Soybean oil & 0.637 & 2.289 \\
\hline MHA $^{1}$ & 0.313 & 0.313 \\
\hline L-lysine-50 & 0.751 & 0.759 \\
\hline L-threonine & 0.186 & 0.203 \\
\hline L-tryptophan & 0.034 & 0.030 \\
\hline Calcium carbonate & 0.429 & 0.783 \\
\hline Dicalcium phosphate & 0.890 & 1.298 \\
\hline Sodium chloride & 0.400 & 0.425 \\
\hline Vitamin and mineral premix ${ }^{2}$ & 0.40 & 0.40 \\
\hline Mineral sources ${ }^{3}$ & 0.03 & 0.03 \\
\hline \multicolumn{3}{|c|}{ Analyzed chemical composition (as-fed basis) } \\
\hline $\mathrm{CP}(\%)$ & 18.5 & 17.3 \\
\hline Ether extract $(\%)$ & 5.8 & 6.6 \\
\hline Ash $(\%)$ & 5.9 & 5.4 \\
\hline \multicolumn{3}{|l|}{ Calculated nutrients $^{4}$} \\
\hline $\mathrm{NE}(\mathrm{kcal} / \mathrm{kg})$ & 2,470 & 2,450 \\
\hline $\mathrm{Ca}(\%)$ & 0.70 & 0.75 \\
\hline Available P $(\%)$ & 0.40 & 0.36 \\
\hline $\begin{array}{l}\text { Standardized ileal } \\
\text { digestible Lys }(\%)\end{array}$ & 1.25 & 1.15 \\
\hline TSAA/Lys & 64 & 66 \\
\hline Thr/Lys & 65 & 65 \\
\hline
\end{tabular}

${ }^{1}$ MHA is a calcium salt of 2-hydroxy-4-methylthio butanoic acid.

${ }^{2}$ Provided per kg of diet: vitamin A 10,000 IU; vitamin D 2,000 IU; vitamin $\mathrm{E}$ ( $\alpha$-tocopherol) $100 \mathrm{mg}$; vitamin $\mathrm{K}_{3} 5 \mathrm{mg}$; vitamin $\mathrm{B}_{1} 1.5 \mathrm{mg}$; vitamin $\mathrm{B}_{2} 5 \mathrm{mg}$; vitamin $\mathrm{B}_{6} 4 \mathrm{mg}$; vitamin $\mathrm{B}_{12} 30 \mu \mathrm{g}$; nicotinic acid 25 $\mathrm{mg}$; pantothenic acid $20 \mathrm{mg}$; folic acid $1 \mathrm{mg}$; biotin $100 \mu \mathrm{g}$; choline chloride $200 \mathrm{mg}$; Co $0.50 \mathrm{mg}$; Fe $100 \mathrm{mg}$; I $2.00 \mathrm{mg}$; Se $0.20 \mathrm{mg}$.

${ }^{3}$ Supplemented $\mathrm{Zn}, \mathrm{Mn}$, and $\mathrm{Cu}$ from either sulfates or $\mathrm{Cu}(\mathrm{HMTBa})_{2}$ following experimental design.

${ }^{4}$ Based on FEDNA (2003) values for feed ingredients.

for $\mathrm{Cu}$ deposition analysis (AOAC 968.08).

\section{Exp. 2: Comparison of different $\mathrm{Cu}$ sources as growth promoter in nursery pigs}

A total of 616 crossbred piglets (PIC, 20 days of age, $5.02 \pm 0.25 \mathrm{~kg}$ ) were randomly allocated to 4 experimental treatments based on sex and BW with 7 replicates for each treatment and 22 piglets per pen. The treatments included a $\mathrm{NRC}$ negative control $\left(6 \mathrm{mg} / \mathrm{kg} \mathrm{Cu}\right.$ from $\left.\mathrm{CuSO}_{4}\right)$, and 3 treatments supplemented with different $\mathrm{Cu}$ sources $(\mathrm{CuSO} 4$,
$\mathrm{Cu}_{2}[\mathrm{OH}]_{3} \mathrm{Cl}$, and $\mathrm{Cu}[\mathrm{HMTBa}]_{2}$ ) at $150 \mathrm{mg} / \mathrm{kg}$. The pens were slatted and ventilation was achieved by single, variable-speed fans linked to temperature sensors. Diets were provided ad libitum throughout the trial from hoppers and water from 2 nipple drinkers per pen.

Typical North American commercial nursery diets (corn-soybean meal) were formulated to meet or exceed NRC (1998) requirement (Table 3). High Zn (3,000 mg/kg) from zinc oxide was included during the first seven days post-weaning as typical commercial practice. Diets were analyzed for $\mathrm{Cu}$ content using atomic absorption spectrometry (AOAC 968.08). Weight gain, feed intake and feed efficiency were determined for the whole experimental period ( 21 days post-weaning). At the end of the trial, one medium-size piglet per pen was slaughtered for liver mineral analysis.

Table 3. Basal diet formula and nutrient profile (Exp. 2)

\begin{tabular}{|c|c|c|}
\hline Ingredients (\%) & $\begin{array}{l}\text { Phase I } \\
\text { (d } 0 \text { to } 7 \text { ) }\end{array}$ & $\begin{array}{l}\text { Phase II } \\
\text { (d } 7 \text { to } 21 \text { ) }\end{array}$ \\
\hline Corn & 38.38 & 46.26 \\
\hline Soybean meal & 15.0 & 25.0 \\
\hline Dairy-Lac 80 & 24.4 & 12.2 \\
\hline Poultry meal & 7.38 & 6.16 \\
\hline Fish meal & 5.50 & 3.00 \\
\hline Spray-dried plasma protein & 3.0 & - \\
\hline Choice white grease & 4.0 & 4.0 \\
\hline Mono calcium phosphate & - & 0.91 \\
\hline Limestone & 0.11 & 0.29 \\
\hline L-lysine-HCL, 78\% & 0.30 & 0.30 \\
\hline Threonine & 0.16 & 0.14 \\
\hline $\mathrm{MHA}^{1}$ & 0.26 & 0.23 \\
\hline Salt & 0.40 & 0.40 \\
\hline $\mathrm{ZnO}$ & 0.42 & 0.42 \\
\hline Vitamin premix ${ }^{2}$ & 0.25 & 0.25 \\
\hline Mineral premix ${ }^{3}$ & 0.15 & 0.15 \\
\hline Antibiotics & 0.29 & 0.29 \\
\hline \multicolumn{3}{|c|}{ Analyzed chemical composition (as-fed basis) } \\
\hline $\mathrm{CP}(\%)$ & 22.06 & 21.64 \\
\hline Ether extract (\%) & 7.39 & 7.32 \\
\hline Ash (\%) & 7.53 & 6.95 \\
\hline \multicolumn{3}{|l|}{ Calculated nutrients } \\
\hline $\mathrm{ME}(\mathrm{kcal} / \mathrm{kg})$ & 3,256 & 3,217 \\
\hline $\mathrm{Ca}(\%)$ & 0.80 & 0.80 \\
\hline Available P (\%) & 0.47 & 0.45 \\
\hline $\begin{array}{l}\text { Standardized ileal } \\
\text { digestible Lys (\%) }\end{array}$ & 1.40 & 1.35 \\
\hline TSAA/Lys & 60 & 60 \\
\hline Thr/Lys & 65 & 65 \\
\hline
\end{tabular}

${ }^{1}$ MHA is a calcium salt of 2-hydroxy-4-methylthio butanoic acid.

${ }^{2,3}$ Provide per kg of final diet: vitamin A 10,000 IU; vitamin D 8,800 IU; vitamin E $220 \mathrm{IU}$; vitamin K $22 \mathrm{mg}$; vitamin $\mathrm{B}_{12} 19.25 \mathrm{mg}$; niacin 250 $\mathrm{mg}$; pantothenic acid $137 \mathrm{mg}$; riboflavin $41.25 \mathrm{mg}$; I $0.26 \mathrm{mg}$; Fe 140 mg; Mn 30 mg; Se 0.25 mg; and Zn 140 mg. 
Exp. 3: Benefits of $\mathrm{Cu}(\mathrm{HMBa})_{2}$ on growth performance and carcass traits in grower-finisher pigs

The third experiment was designed to investigate whether $\mathrm{Cu}(\mathrm{HMTBa})_{2}$ can replace high dietary $\mathrm{CuSO}_{4}$ as growth promoter in grower-finisher pigs. A total of 1,048 pigs (PIC C22, 32.36 $\pm 0.29 \mathrm{~kg}$ ) were allotted to 1 of 6 dietary treatments in a randomized complete block design with 8 pens per treatment and 20 to 22 pigs per pen based on BW and gender. Gilts and barrows were housed separately in an environmentally controlled room with access to feed and water ad libitum. All pigs were fed a $\mathrm{Cu}$ deficient diet for the first 21 days then switched to experimental diets. The treatments included a basal control with $4 \mathrm{mg} / \mathrm{kg} \mathrm{Cu}$ from $\mathrm{CuSO}_{4}$, a positive control with 160 $\mathrm{mg} / \mathrm{kg} \mathrm{Cu}$ from $\mathrm{CuSO}_{4}$, and incremental levels of $\mathrm{Cu}(\mathrm{HMTBa})_{2}$ at 20, 40, 80, or $160 \mathrm{mg} / \mathrm{kg}$. Different $\mathrm{Cu}(\mathrm{HMTBa})_{2}$ doses were mixed by blending the highest level $(160 \mathrm{mg} / \mathrm{kg})$ with the basal to make targeted doses in the final diets. Pigs were fed five phases diets of $\mathrm{d} 0$ to 21 (30 to $50 \mathrm{~kg}$ ), d 22 to 42 (50 to $70 \mathrm{~kg}$ ), d 43 to 62 (70 to 90 $\mathrm{kg}$ ), d 63 to 80 (90 to $100 \mathrm{~kg}$ ), and d 81 to 100 (100 to 120 $\mathrm{kg}$ ). Corn-soybean meal-dried distillers grains with solubles (DDGs) diets were made to satisfy NRC (1998) requirements (Table 4$)$. Ractopamine $(4.5 \mathrm{mg} / \mathrm{kg}$ ) was used in the last 28 days before marketing. Pen weight and feed intake were collected for each feeding phase and feed efficiency was calculated and adjusted for mortality. At the end of the study, all pigs were harvested at the same time at a Missouri process plant and carcass traits were recorded on a pen basis.

\section{Statistical analyses}

Data were analyzed as a randomized completely block design ANOVA using GLM of SAS 9.0 (SAS Institute, 2002). In experiment three, linear and quadratic effects of $\mathrm{Cu}(\mathrm{HMTBa})_{2}$ were analyzed. Pen was the experimental unit. Statistical significance was declared at $\mathrm{p} \leq 0.05$, with $0.05<\mathrm{p} \leq 0.10$ considered as a near-significant trend.

\section{RESULTS}

\section{Analyzed dietary $\mathrm{Cu}$ level}

Analyzed dietary $\mathrm{Cu}$ levels in Exp. 1 were 15, 149, and $169 \mathrm{mg} / \mathrm{kg}$ in phase I and 11, 145, and $160 \mathrm{mg} / \mathrm{kg}$ in phase II, which were similar to the targeted levels of 6,170 , and $170 \mathrm{mg} / \mathrm{kg}$ added $\mathrm{Cu}$, respectively. In Exp. 2, the analyzed $\mathrm{Cu}$ levels were $19,117,162$, and $208 \mathrm{mg} / \mathrm{kg}$ in phase I and $14,154,140$, and $188 \mathrm{mg} / \mathrm{kg}$ in phase II, respectively. Dietary $\mathrm{Cu}$ was not analyzed in Exp. 3.

\section{Exp. 1}

At the end of the study, pigs fed $\mathrm{Cu}(\mathrm{HMTBa})_{2}$ were

Table 4. Basal diets composition and nutrient profile (Exp. 3)

\begin{tabular}{|c|c|c|c|c|c|}
\hline Ingredients (\%) & Phase I & Phase II & Phase III & Phase IV & Phase V \\
\hline Corn & 57.91 & 63.88 & 67.65 & 77.43 & 69.77 \\
\hline Dried distillers grain with solubles & 20.00 & 20.00 & 20.00 & 10.00 & 16.68 \\
\hline Soybean meal & 17.83 & 11.86 & 8.12 & 8.00 & 10.00 \\
\hline Choice white grease & 1.93 & 1.93 & 1.93 & 2.19 & 1.00 \\
\hline Limestone & 1.06 & 1.09 & 1.10 & 0.90 & 0.87 \\
\hline Sodium chloride & 0.50 & 0.50 & 0.50 & 0.50 & 0.50 \\
\hline L-lysine-HCL, 78\% & 0.40 & 0.40 & 0.38 & 0.32 & 0.40 \\
\hline Threonine & 0.11 & 0.09 & 0.07 & 0.06 & 0.12 \\
\hline Alimet $^{1}$ & 0.07 & 0.03 & 0.00 & 0.00 & 0.07 \\
\hline Mono calcium phosphate & 0.04 & 0.07 & 0.10 & 0.45 & 0.40 \\
\hline Mineral and vitamin premix ${ }^{2}$ & 0.13 & 0.13 & 0.13 & 0.13 & 0.13 \\
\hline Phytase & 0.02 & 0.02 & 0.02 & 0.02 & 0.02 \\
\hline Ractopamine hydrochloride & & & & & 0.04 \\
\hline \multicolumn{6}{|l|}{ Calculated nutrient profile } \\
\hline $\mathrm{ME}(\mathrm{kcal} / \mathrm{kg})$ & 3,400 & 3,400 & 3,400 & 3,428 & 3,374 \\
\hline $\mathrm{CP}(\%)$ & 19.30 & 16.85 & 15.34 & 13.34 & 17.00 \\
\hline $\mathrm{Ca}(\%)$ & 0.5 & 0.5 & 0.5 & 0.5 & 0.5 \\
\hline Available P (\%) & 0.3 & 0.2 & 0.2 & 0.2 & 0.2 \\
\hline Standardized ileal digestible Lys (\%) & 1.00 & 0.85 & 0.74 & 0.67 & 0.95 \\
\hline Met/Lys & 58 & 64 & 68 & 72 & 66 \\
\hline Thr/Lys & 65 & 65 & 65 & 65 & 65 \\
\hline Trp/Lys & 16 & 15 & 15 & 15 & 15 \\
\hline
\end{tabular}

${ }^{1}$ Alimet: Brand name of 2-hydroxy-4-methylthio butanoic acid.

${ }^{2}$ Provided per kg of final diet: vitamin A 10,000 IU; vitamin D 8,800 IU; vitamin E $220 \mathrm{IU}$; vitamin K $22 \mathrm{mg}$; vitamin B 12 19.25 mg; niacin $250 \mathrm{mg}$; pantothenic acid $137 \mathrm{mg}$; riboflavin $41.25 \mathrm{mg}$; I $0.26 \mathrm{mg}$; Fe $140 \mathrm{mg}$; Mn $30 \mathrm{mg}$; Se $0.25 \mathrm{mg}$; and Zn $140 \mathrm{mg}$. 
Table 5. Effects of $\mathrm{Cu}(\mathrm{HMTBa})_{2}$ and $\mathrm{CuSO}_{4}$ on performance in Exp. $1^{1}$

\begin{tabular}{|c|c|c|c|c|c|}
\hline & $\begin{array}{c}\mathrm{NRC} \text { control } \\
\mathrm{CuSO}_{4},(6 \mathrm{mg} / \mathrm{kg})\end{array}$ & $\begin{array}{c}\mathrm{CuSO}_{4} \\
170 \mathrm{mg} / \mathrm{kg}\end{array}$ & $\begin{array}{c}\mathrm{Cu}(\mathrm{HMTBa})_{2} \\
170 \mathrm{mg} / \mathrm{kg}\end{array}$ & SEM & $\mathrm{p}$-value \\
\hline \multicolumn{6}{|c|}{ Pig body weight (kg) } \\
\hline d 0 & 7.36 & 7.36 & 7.35 & 0.10 & 0.99 \\
\hline d 14 & 10.44 & 10.54 & 11.27 & 0.24 & 0.06 \\
\hline $\mathrm{d} 42$ & $22.07^{\mathrm{b}}$ & $22.07^{\mathrm{b}}$ & $23.40^{\mathrm{a}}$ & 0.37 & 0.03 \\
\hline \multicolumn{6}{|l|}{ d 0 to 14} \\
\hline ADG (g) & $220^{\mathrm{b}}$ & $227^{\mathrm{b}}$ & $279^{\mathrm{a}}$ & 12 & $<0.01$ \\
\hline ADFI $(\mathrm{g})$ & $310^{\mathrm{b}}$ & $324^{\mathrm{b}}$ & $352^{\mathrm{a}}$ & 9 & 0.01 \\
\hline Gain:feed & $0.709^{\mathrm{a}}$ & $0.701^{\mathrm{a}}$ & $0.793^{\mathrm{b}}$ & 0.026 & 0.05 \\
\hline \multicolumn{6}{|l|}{ d 15 to 42} \\
\hline ADG (g) & 408 & 405 & 393 & 12 & 0.17 \\
\hline ADFI (g) & 644 & 601 & 608 & 16 & 0.17 \\
\hline Gain:feed & 0.633 & 0.674 & 0.646 & 0.017 & 0.31 \\
\hline \multicolumn{6}{|l|}{ d 0 to 42} \\
\hline ADG (g) & $346^{\mathrm{b}}$ & $346^{\mathrm{b}}$ & $378^{\mathrm{a}}$ & 7 & 0.01 \\
\hline ADFI (g) & 537 & 510 & 544 & 10 & 0.09 \\
\hline Gain:Feed & 0.644 & 0.678 & 0.695 & 0.013 & 0.06 \\
\hline
\end{tabular}

${ }^{a, b}$ Means in a row with no common superscripts significantly differ $(\mathrm{p}<0.05)$.

${ }^{1}$ Values represent the means of 8 pens with 10 pigs per pen.

$6.0 \%$ heavier than pigs fed the $\mathrm{NRC}$ control or $\mathrm{CuSO}_{4}$ at the same level ( $\mathrm{p}=0.03$, Table 5). During phase I (d 0 to 14$)$, piglets fed $\mathrm{Cu}(\mathrm{HMTBa})_{2}$ gained $22.9 \%$ more weight $(279$ vs $227 \mathrm{~g} / \mathrm{d}, \mathrm{p}<0.01$ ), ate $8.6 \%$ more feed (352 vs $324 \mathrm{~g} / \mathrm{d}, \mathrm{p}$ $=0.01)$, and had better feed conversion $(0.79$ vs $0.70, \mathrm{p}=$ 0.05) than animals fed $170 \mathrm{mg} / \mathrm{kg} \mathrm{CuSO}_{4}$. No difference was observed between pigs fed the NRC control $(\mathrm{Cu}, \mathrm{Mn}$, and $\mathrm{Zn}$ ) and $\mathrm{CuSO}_{4}$ at EU maximum level. In phase II (d 14 to 42 ), no differences were observed among treatments ( $\mathrm{p}>$ 0.17). Overall, piglets fed $\mathrm{Cu}(\mathrm{HMTBa})_{2}$ gained $9.0 \%$ more $(\mathrm{p}=0.01)$ and tended to eat more feed $(\mathrm{p}=0.09)$ than animals fed $170 \mathrm{mg} / \mathrm{kg} \mathrm{CuSO}_{4}$. Feed conversion rate tended to be improved with $\mathrm{Cu}(\mathrm{HMTBa})_{2}$ supplementation compared with the other two treatments $(p=0.06)$.

Liver $\mathrm{Cu}$ was increased 2.7 times with $170 \mathrm{mg} / \mathrm{kg}$ $\mathrm{CuSO}_{4}$ supplementation compared with the NRC control, and was further increased with $\mathrm{Cu}(\mathrm{HMTBa})_{2}$ (4.5 times, $\mathrm{p}<$ 0.05 , Table 6). No significant differences were observed on $\mathrm{Cu}$ deposition in tibia bone, kidney, muscle, and skin and fat $(p>0.23)$.

\section{Exp. 2}

Pigs fed $\mathrm{CuSO}_{4}$ and $\mathrm{Cu}(\mathrm{HMTBa})_{2}$ tended to have better ADG $(p=0.08)$ and improved feed efficiency $(p=0.01)$ compared with the NRC control (Table 7). The $\mathrm{Cu}_{2}(\mathrm{OH})_{3} \mathrm{Cl}$ was intermediate and did not differ from the NRC control. No difference was observed on feed intake among treatments $(\mathrm{p}=0.81)$.

Liver $\mathrm{Cu}$ was significantly increased with $\mathrm{Cu}(\mathrm{HMTBa})_{2}$ compared with the control and $\mathrm{Cu}_{2}(\mathrm{OH})_{3} \mathrm{Cl}$ while $\mathrm{CuSO}_{4}$ was intermediate $(\mathrm{p}=0.01$, Table 8$)$. No difference was observed on liver Fe, $\mathrm{Zn}$, and Mn concentration ( $\mathrm{p}>0.27$ ).

\section{Exp. 3}

Pigs fed $80 \mathrm{mg} / \mathrm{kg} \mathrm{Cu}(\mathrm{HMTBa})_{2}$ tended to be heavier than those fed either the NRC control or $160 \mathrm{mg} / \mathrm{kg} \mathrm{CuSO}_{4}$ at the end of experiment ( $\mathrm{p}=0.07$, Table 9). Compared with the negative control, $160 \mathrm{mg} / \mathrm{kg} \mathrm{CuSO}$ improved weight gain and feed intake during the phase (d 21 to 42) immediately after 21 days of depletion $(\mathrm{p}<0.05)$. No benefit of $160 \mathrm{mg} / \mathrm{kg} \mathrm{CuSO}{ }_{4}$ was observed during all other phases

Table 6. Effects of $\mathrm{Cu}(\mathrm{HMTBa})_{2}$ and $\mathrm{CuSO}_{4}$ on tissue $\mathrm{Cu}$ concentration (DM basis, Exp. 1) ${ }^{\mathbf{1}}$

\begin{tabular}{lccccc}
\hline $\begin{array}{l}\text { Tissues } \mathrm{Cu}^{2} \\
\mathrm{mg} / \mathrm{kg}\end{array}$ & $\begin{array}{c}\mathrm{NRC}^{2} \text { control } \\
\mathrm{CuSO}_{4}, 6 \mathrm{mg} / \mathrm{kg}\end{array}$ & $\begin{array}{c}\mathrm{CuSO}_{4} \\
170 \mathrm{mg} / \mathrm{kg}\end{array}$ & $\begin{array}{c}\mathrm{Cu}(\mathrm{HMTBa})_{2} \\
170 \mathrm{mg} / \mathrm{kg}\end{array}$ & \multirow{2}{*}{ SEM } & p-value \\
\hline Tibia bone & 0.64 & 0.64 & 0.76 & 0.07 & 0.40 \\
Kidney & 3.59 & 3.69 & 4.58 & 0.42 & 0.23 \\
Liver & $6.83^{\mathrm{b}}$ & $18.37^{\mathrm{ab}}$ & $30.46^{\mathrm{a}}$ & 0.41 & $<0.01$ \\
Muscle & 0.56 & 0.51 & 0.53 & 0.03 & 0.53 \\
Skin and fat & 1.06 & 1.41 & 1.40 & 0.19 & 0.35 \\
\hline
\end{tabular}

\footnotetext{
${ }_{\mathrm{a}, \mathrm{b}}$ Means in a row with no common superscripts significantly differ $(\mathrm{p}<0.05)$.

${ }^{1}$ Values represent the means of 8 pigs per treatment.

${ }^{2} \mathrm{Cu}$ content was analyzed using atomic absorption spectrometry following AOAC 968.08.
} 
Table 7. Effects of different $\mathrm{Cu}$ supplementation on performance (Exp. 2) ${ }^{1}$

\begin{tabular}{|c|c|c|c|c|c|c|}
\hline & NRC control & $\mathrm{CuSO}_{4}$ & $\mathrm{Cu}_{2}(\mathrm{OH})_{3} \mathrm{Cl}$ & $\mathrm{Cu}(\mathrm{HMTBa})_{2}$ & SEM & p-value \\
\hline \multicolumn{7}{|c|}{ Body weight (kg) } \\
\hline $\mathrm{d} 0$ & 5.02 & 5.02 & 5.01 & 5.01 & 0.25 & 1.00 \\
\hline $\mathrm{d} 21$ & 10.04 & 10.71 & 10.64 & 10.82 & 0.43 & 0.59 \\
\hline \multicolumn{7}{|l|}{ d 0 to 21} \\
\hline ADG (g) & 238 & 271 & 266 & 280 & 11 & 0.08 \\
\hline ADFI (g) & 316 & 335 & 334 & 335 & 16 & 0.81 \\
\hline Gain:feed & $0.753^{\mathrm{b}}$ & $0.814^{\mathrm{a}}$ & $0.798^{\mathrm{ab}}$ & $0.825^{\mathrm{a}}$ & 0.015 & 0.01 \\
\hline
\end{tabular}

${ }^{\mathrm{a}, \mathrm{b}}$ Means in a row with no common superscripts significantly differ $(\mathrm{p}<0.05)$.

${ }^{1}$ Values represent the means of 7 pens with 22 pigs per pen.

Table 8. Effects of different $\mathrm{Cu}$ sources on liver mineral concentrations (DM basis, Exp. 2) ${ }^{1}$

\begin{tabular}{|c|c|c|c|c|c|c|}
\hline$\overline{\text { Parameters }^{2}}$ & NRC control & $\mathrm{CuSO}_{4}$ & $\mathrm{Cu}_{2}(\mathrm{OH})_{3} \mathrm{CL}$ & $\mathrm{Cu}(\mathrm{HMTBa})_{2}$ & SEM & p-value \\
\hline $\mathrm{Cu}(\mathrm{mg} / \mathrm{kg})$ & $39.82^{\mathrm{b}}$ & $52.12^{\mathrm{ab}}$ & $48.80^{\mathrm{b}}$ & $73.32^{\mathrm{a}}$ & 8.52 & 0.01 \\
\hline $\mathrm{Fe}(\mathrm{mg} / \mathrm{kg})$ & 436.3 & 501.8 & 475.4 & 550.5 & 48.7 & 0.27 \\
\hline $\mathrm{Mn}(\mathrm{mg} / \mathrm{kg})$ & 10.12 & 8.38 & 9.00 & 9.43 & 0.78 & 0.46 \\
\hline $\mathrm{Zn}(\mathrm{mg} / \mathrm{kg})$ & 776.7 & 909.7 & 918.9 & 916.4 & 108.9 & 0.73 \\
\hline
\end{tabular}

${ }_{\mathrm{a}, \mathrm{b}}$ Means in a row with no common superscripts significantly differ $(\mathrm{p}<0.05)$.

${ }^{1}$ Values represent the means of 7 pigs per treatment.

${ }^{2}$ Mineral content was analyzed using atomic absorption spectrometry following AOAC 968.08.

and overall. Due to variation in different phases, only overall effects of $\mathrm{Cu}(\mathrm{HMTBa})_{2}$ are discussed in this paper. Linear and quadratic dose response was observed on weight gain $(\mathrm{p}<0.01)$ and feed efficiency $(\mathrm{p}=0.05)$ with $\mathrm{Cu}(\mathrm{HMTBa})_{2}$ supplementation with the best performance was observed at $80 \mathrm{mg} / \mathrm{kg}$. Pigs fed $80 \mathrm{mg} / \mathrm{kg} \mathrm{Cu}(\mathrm{HMTBa})_{2}$ tended to have improved weight gain $(\mathrm{p}=0.07)$ and feed efficiency $(p=0.10)$ compared with those fed either the $\mathrm{NRC}$ control or $160 \mathrm{mg} / \mathrm{kg} \mathrm{Cu}$ from $\mathrm{CuSO}_{4}$.

Pigs fed $80 \mathrm{mg} / \mathrm{kg} \mathrm{Cu}(\mathrm{HMTBa})_{2}$ had the heaviest carcass weight, which was significant differ from those fed either the NRC control or $\mathrm{CuSO}_{4}$ at $160 \mathrm{mg} / \mathrm{kg}(\mathrm{p}<0.01$, Table 10). Linear dose response of $\mathrm{Cu}(\mathrm{HMTBa})_{2}$ was observed on loin depth with 55.73, 55.96, 56.64, 58.12, and $58.12 \mathrm{~mm}$ for the NRC control, and $\mathrm{Cu}(\mathrm{HMTBa})_{2}$ at 20, 40, 80 , or $160 \mathrm{mg} / \mathrm{kg}$, respectively $(\mathrm{p}=0.04)$. Loin depth from pigs fed $80 \mathrm{mg} / \mathrm{kg}$ and $160 \mathrm{mg} / \mathrm{kg} \mathrm{Cu}(\mathrm{HMTBa})_{2}$ were significantly greater than pigs fed $160 \mathrm{mg} / \mathrm{kg} \mathrm{CuSO}{ }_{4}$ and the NRC control. No treatment difference was observed on back fat, yield, and lean percentage ( $p>0.37)$. In summary, no benefit of $160 \mathrm{mg} / \mathrm{kg} \mathrm{CuSO}{ }_{4}$ was observed on carcass traits and BW. Growth performance, final carcass weight, and loin depth increased with increased $\mathrm{Cu}(\mathrm{HMTBa})_{2}$ supplementation with the best performance was observed with $80 \mathrm{mg} / \mathrm{kg} \mathrm{Cu}(\mathrm{HMTBa})_{2}$.

\section{DISCUSSION}

High level of $\mathrm{CuSO}_{4}$ is typically used in the swine industry as growth promoter and its benefits on weight gain and feed efficiency have been well documented (Bunch et al., 1961;1963). Braude (1967) recorded 83 studies involving a total of 1,215 pigs in each treatment ( 0 vs 250 $\mathrm{mg} / \mathrm{kg}$ ) and reported that $\mathrm{CuSO}_{4}$ improved daily weight gain on average $8.1 \%$, and feed efficiency on average $5.4 \%$. The optimum dose of $\mathrm{CuSO}_{4}$ as growth promoter is around $242 \mathrm{mg} / \mathrm{kg}$ and $125 \mathrm{mg} / \mathrm{kg}$ of $\mathrm{Cu}$ was approximately $75 \%$ as effective (Cromwell et al., 1989). In agreement with previous studies, $\mathrm{CuSO}_{4}$ improved weight gain and feed efficiency in the current nursery studies. In addition, $\mathrm{Cu}(\mathrm{HMTBa})_{2}$ is more effective compared with $\mathrm{CuSO}_{4}$ as growth promoter in stimulating gain and feed efficiency in both nursery and finisher pigs. These results agree with Coffey et al. (1994) and Veum et al. (2004) that chelated $\mathrm{Cu}$ is more effective than $\mathrm{CuSO}_{4}$ and less is required to achieve similar performance. With limited $\mathrm{Cu}$ supplementation allowance in swine diets, using chelated $\mathrm{Cu}$ could be an alternative to pharmaceutical $\mathrm{Cu}$ to maintain growth promoting effects and reduce $\mathrm{Cu}$ excretion to the environment. The growth advantage of chelated $\mathrm{Cu}$ is perhaps due to the fact it is more available for absorption and less antagonism in the lumen as indicated by increased liver $\mathrm{Cu}$ storage and better antibacterial function.

It has been proposed that $\mathrm{CuSO}_{4}$ acts as an anti-bacterial agent by shifting the microbial population within the gastrointestinal tract (Apgar et al., 1995; Arias and Koutsos, 2006), by quantitatively modifying some gram-positive bacterial populations in the gut. Evidence that $\mathrm{Cu}$ produces a growth promoting effect possibly through the microbial gut flora is supported by Shurson et al. (1990), who observed a positive effect of high concentration (283 $\mathrm{mg} / \mathrm{kg}$ ) of $\mathrm{Cu}$ in the diet on daily growth rate and feed 
Table 9. Effects of $\mathrm{CuSO}_{4}$ and $\mathrm{Cu}(\mathrm{HMTBa})_{2}$ on performance in grower-finisher pigs (Exp. 3) ${ }^{1,2}$

\begin{tabular}{|c|c|c|c|c|c|c|c|c|c|c|}
\hline \multirow{2}{*}{$\begin{array}{l}\text { Treatments } \\
\mathrm{mg} / \mathrm{kg}\end{array}$} & \multicolumn{2}{|c|}{$\mathrm{CuSO}_{4}$} & \multicolumn{4}{|c|}{$\mathrm{Cu}(\mathrm{HMTBa})_{2}$} & \multirow{2}{*}{ SEM } & \multicolumn{3}{|c|}{$\mathrm{p}$-value } \\
\hline & 4 & 160 & 20 & 40 & 80 & 160 & & Treatment & Linear & Quadratic \\
\hline \multicolumn{11}{|c|}{ Body weight (kg) } \\
\hline $\mathrm{d} 0$ & 32.29 & 32.42 & 32.52 & 32.33 & 32.22 & 32.40 & 0.29 & 0.98 & - & - \\
\hline d 21 & 52.57 & 52.58 & 52.52 & 52.60 & 52.54 & 52.56 & 0.30 & 1.00 & 0.99 & 0.99 \\
\hline $\mathrm{d} 42$ & 72.16 & 73.43 & 72.00 & 71.75 & 72.41 & 72.88 & 0.42 & 0.08 & 0.89 & 0.99 \\
\hline d 62 & 89.45 & 90.54 & 89.35 & 89.52 & 89.38 & 90.27 & 0.43 & 0.24 & 0.88 & 0.75 \\
\hline d 80 & 101.69 & 101.88 & 100.69 & 100.92 & 101.98 & 102.48 & 0.57 & 0.24 & 0.96 & 0.75 \\
\hline d 100 & 117.54 & 117.86 & 117.28 & 118.22 & 119.67 & 118.91 & 0.60 & 0.07 & 0.14 & 0.25 \\
\hline \multicolumn{11}{|l|}{ d 0 to 21} \\
\hline ADG (kg) & 0.967 & 0.960 & 0.952 & 0.960 & 0.968 & 0.956 & 0.007 & 0.62 & 0.36 & 0.37 \\
\hline ADFI (kg) & 1.899 & 1.865 & 1.870 & 1.865 & 1.881 & 1.874 & 0.015 & 0.61 & 0.83 & 0.85 \\
\hline Gain:feed & 0.511 & 0.516 & 0.509 & 0.516 & 0.513 & 0.510 & 0.004 & 0.67 & 0.55 & 0.51 \\
\hline \multicolumn{11}{|l|}{ d 21 to 42} \\
\hline ADG $(\mathrm{kg})$ & $0.932^{\text {bcd }}$ & $0.988^{\mathrm{a}}$ & $0.927^{\mathrm{cd}}$ & $0.907^{\mathrm{d}}$ & $0.947^{\mathrm{bc}}$ & $0.961^{\mathrm{ab}}$ & 0.011 & $<0.01$ & 0.65 & 0.95 \\
\hline ADFI (kg) & $2.405^{\mathrm{bc}}$ & $2.486^{\mathrm{a}}$ & $2.411^{\mathrm{bc}}$ & $2.363^{c}$ & $2.418^{\mathrm{abc}}$ & $2.445^{\mathrm{ab}}$ & 0.026 & 0.04 & 0.95 & 0.82 \\
\hline Gain:feed & $0.389^{\mathrm{abc}}$ & $0.398^{\mathrm{a}}$ & $0.384^{c}$ & $0.385^{b c}$ & $0.394^{\mathrm{ab}}$ & $0.394^{\mathrm{ab}}$ & 0.003 & 0.04 & 0.19 & 0.32 \\
\hline \multicolumn{11}{|l|}{ d 42 to 62} \\
\hline ADG (kg) & 0.865 & 0.849 & 0.868 & 0.889 & 0.847 & 0.873 & 0.011 & 0.11 & 0.26 & 0.27 \\
\hline ADFI (kg) & 2.561 & 2.555 & 2.536 & 2.553 & 2.525 & 2.555 & 0.026 & 0.92 & 0.83 & 0.80 \\
\hline Gain:feed & 0.339 & 0.335 & 0.343 & 0.350 & 0.335 & 0.343 & 0.004 & 0.16 & 0.36 & 0.40 \\
\hline \multicolumn{11}{|l|}{ d 62 to 80} \\
\hline ADG (kg) & $0.680^{\mathrm{ab}}$ & $0.630^{\mathrm{bc}}$ & $0.619^{c}$ & $0.634^{b c}$ & $0.699^{\mathrm{a}}$ & $0.665^{\mathrm{abc}}$ & 0.017 & 0.02 & $<0.01$ & $<0.01$ \\
\hline $\mathrm{ADFI}(\mathrm{kg})$ & 2.434 & 2.391 & 2.386 & 2.277 & 2.459 & 2.458 & 0.008 & 0.12 & 0.46 & 0.62 \\
\hline Gain:feed & 0.280 & 0.263 & 0.258 & 0.289 & 0.285 & 0.271 & 0.01 & 0.31 & 0.19 & 0.19 \\
\hline \multicolumn{11}{|l|}{ d 80 to 100} \\
\hline ADG (kg) & 0.835 & 0.791 & 0.816 & 0.837 & 0.876 & 0.821 & 0.02 & 0.10 & 0.06 & 0.06 \\
\hline ADFI (kg) & 2.340 & 2.266 & 2.332 & 2.399 & 2.343 & 2.292 & 0.05 & 0.58 & 0.74 & 0.60 \\
\hline Gain:feed & 0.358 & 0.350 & 0.351 & 0.350 & 0.374 & 0.359 & 0.007 & 0.16 & 0.09 & 0.11 \\
\hline \multicolumn{11}{|l|}{ d 0 to 100} \\
\hline ADG (kg) & 0.858 & 0.852 & 0.840 & 0.856 & 0.872 & 0.857 & 0.007 & 0.07 & $<0.01$ & $<0.01$ \\
\hline ADFI (kg) & 2.315 & 2.308 & 2.303 & 2.289 & 2.319 & 2.317 & 0.015 & 0.75 & 0.81 & 0.89 \\
\hline Gain:feed & 0.370 & 0.371 & 0.365 & 0.373 & 0.378 & 0.369 & 0.003 & 0.10 & 0.05 & 0.05 \\
\hline
\end{tabular}

$\overline{\mathrm{a}, \mathrm{b}, \mathrm{c}, \mathrm{d}}$ Means in a row with no common superscripts significantly differ $(\mathrm{p}<0.05)$.

${ }^{1}$ Values represent the means of 8 pens with 20 to 22 pigs per pen.

${ }^{2}$ All pigs were fed a $\mathrm{Cu}$ deficient diet for the first 21 days (d 0 to 21 ).

conversion rate in conventional pigs and a negative effect in 1994).

germ-free pigs. On the other hand, similar growth- The authors suspect that injected extra $\mathrm{Cu}$ is secreted to the promoting effect was obtained when copper histidinate or bile and back to the gastrointestinal tract, and has similar histidine solution was administered by intravenous injection impact on bacteria population in the lumen as through and thus bypassed the gastrointestinal tract (Zhou et al., dietary supplementation. If this is the case, dietary Cu needs

Table 10. Benefits of $\mathrm{Cu}(\mathrm{HMTBa})_{2}$ on carcass traits in grower-finisher pigs (Exp 3.) ${ }^{1}$

\begin{tabular}{|c|c|c|c|c|c|c|c|c|c|c|}
\hline \multirow{2}{*}{$\begin{array}{l}\text { Treatments } \\
\mathrm{mg} / \mathrm{kg}\end{array}$} & \multicolumn{2}{|c|}{$\mathrm{CuSO}_{4}$} & \multicolumn{4}{|c|}{$\mathrm{Cu}(\mathrm{HMTBa})_{2}$} & \multirow{2}{*}{ SEM } & \multicolumn{3}{|c|}{ p-value } \\
\hline & 4 & 160 & 20 & 40 & 80 & 160 & & Treatment & Linear & Quadratic \\
\hline Carcass wt. (kg) & $88.13^{\mathrm{b}}$ & $88.24^{\mathrm{b}}$ & $88.13^{\mathrm{b}}$ & $88.13^{\mathrm{b}}$ & $90.57^{\mathrm{a}}$ & $89.43^{\mathrm{ab}}$ & 0.51 & $<0.01$ & 0.07 & 0.17 \\
\hline Back fat (mm) & 17.91 & 18.29 & 17.81 & 18.11 & 17.88 & 18.36 & 0.30 & 0.72 & 0.94 & 0.80 \\
\hline Yield (\%) & 74.62 & 74.92 & 75.16 & 73.78 & 74.77 & 74.73 & 0.44 & 0.37 & 0.70 & 0.66 \\
\hline Lean $(\%)$ & 54.63 & 54.33 & 54.72 & 54.64 & 54.93 & 54.56 & 0.19 & 0.38 & 0.58 & 0.55 \\
\hline Loin depth (mm) & $55.73^{\mathrm{c}}$ & $55.19^{c}$ & $55.96^{\mathrm{bc}}$ & $56.64^{\mathrm{abc}}$ & $58.12^{\mathrm{a}}$ & $58.12^{\mathrm{ab}}$ & 0.58 & $<0.01$ & 0.04 & 0.11 \\
\hline
\end{tabular}

\footnotetext{
${ }^{\mathrm{a}, \mathrm{b}, \mathrm{c}}$ Means in a row with no common superscripts significantly differ $(\mathrm{p}<0.05)$.

${ }^{1}$ There were 8 replicates per treatment with 20-22 pigs per pen. All pigs were marketed at the same day.
} 
to be absorbed first in order to be effective, which is the case in this study that $\mathrm{Cu}(\mathrm{HMTBa})_{2}$ was more effective than $\mathrm{CuSO}_{4}$ as growth promoter in both nursery and finisher pigs. Arnold (2011) reported that antimicrobial effects of bile determined by measuring the diameter of the zone of inhibition tended to be higher in $\mathrm{Cu}(\mathrm{HMTBa})_{2}$ treatments compared with $\mathrm{CuSO}_{4}$ at $75 \mathrm{mg} / \mathrm{kg}$. However bile components, intestinal bacterial populations, and small intestine gene expression profiles associated with $\mathrm{Cu}$ absorption and homeostasis (Ctr-1, Atox-1, Cox-17, ATP7a, and ATP7b) were not affected. More research is needed to understand the effects of bile $\mathrm{Cu}$ recycle pathway on growth performance and antibacterial function.

Even though $\mathrm{CuSO}_{4}$ is widely used in the swine industry, there are negative effects of adding high $\mathrm{CuSO}_{4} \cdot \mathrm{CuSO}_{4}$ is highly water soluble and hygroscopic, which drawing moisture to the surface of each crystal. In vitamin premix and diet, $\mathrm{CuSO}_{4}$ acts as a hot spot for reaction that break down labile organic compounds such as vitamins, enzymes, fat and oil (Dove and Ewan, 1991; Marchetti et al., 2000). In vivo, $\mathrm{CuSO}_{4}$ dissociates and generates free $\mathrm{Cu}$ in the stomach, which is very active pro-oxidative substrate and leads to lipid oxidation and cell damage (Ajuwon et al., 2011). Absorption of $\mathrm{Cu}$ by the stomach is much less than what takes place in the intestine and is further hindered by binding with phytic acid and forming insoluble compounds. Banks et al. (2004) reported that $250 \mathrm{mg} / \mathrm{kg} \mathrm{CuSO}_{4}$ reduced apparent $\mathrm{P}$ retention 0.029 percentage-units in broilers, by forming an insoluble $\mathrm{Cu}$-phytate chelate complex. The chelate is insoluble at the $\mathrm{pH}$ of the small intestine, and therefore none of the components of the complex are available for absorption. In addition, $\mathrm{Cu}$ competes with other trace minerals for absorption and utilization, such as $\mathrm{Zn}, \mathrm{Fe}$, and Mn. Hall et al. (1979) reported that a $20 \%$ decrease in ${ }^{65} \mathrm{Zn}$ absorption occurred when dietary $\mathrm{Cu}$ was raised from 3 to $24 \mathrm{mg} / \mathrm{kg}$ in rats. One advantage of chelated mineral is that chelation between ligand(s) and mineral preventing mineral dissociation and complex with other nutrients and consequently avoiding antagonism with other nutrients in the lumen. Previous studies suggested that chelated minerals are more bioavailable and better at avoiding antagonism in vivo based on tissue mineral, gene expression, and functional assays compared with inorganic trace minerals (Richards et al., 2010; Zhao et al., 2010). Because of its higher availability, less $\mathrm{Cu}(\mathrm{HMTBa})_{2}$ can be used to replace high $\mathrm{CuSO}_{4}$ and have similar or better growth promoter effects in pigs. Our follow-up study indicated that pigs fed $50 \mathrm{mg} / \mathrm{kg} \mathrm{Cu}(\mathrm{HMTBa})_{2}$ performed equally as pigs fed $250 \mathrm{mg} / \mathrm{kg} \mathrm{CuSO}$ (Zhao et al., 2009). Similar results were reported in broilers that reduced level of chelated trace minerals can be used to replace inorganic trace mineral and have similar or even better performance (Zhao et al., 2010). Additional benefit of using chelated trace mineral is reduced mineral excretion to the environment (Managi et al., 2010).

Using high $\mathrm{CuSO}_{4}$ in grower-finisher pigs is less common and research results are controversial. Cromwell et al. (1978) reported 3\% improvement of gain and feed efficiency with $250 \mathrm{mg} / \mathrm{kg} \mathrm{CuSO}_{4}$ supplementation. No significant benefit of $250 \mathrm{mg} / \mathrm{kg} \mathrm{CuSO}$ was observed by Gipp et al. (1973) and Dove and Ewan (1991). This is in agreement with the current study that the only benefit of $160 \mathrm{mg} / \mathrm{kg} \mathrm{CuSO}_{4}$ was observed during the first 21 days immediately after a three-week depletion period. Interestingly, quadratic dose response was observed on growth performance, carcass weight, and loin depth with pigs fed $80 \mathrm{mg} / \mathrm{kg} \mathrm{Cu}(\mathrm{HMTBa})_{2}$ had the best gain and the greatest loin depth. Mechanism of $\mathrm{Cu}(\mathrm{HMTBa})_{2}$ improved loin depth is not well understood. Zhou et al. (1994) suggested that $\mathrm{Cu}$ stimulated the growth of longissimus muscle more than the growth of the whole body, potentially through stimulating growth hormone secretion. The same authors also reported increased $\mathrm{Cu}$ concentration in the brain, which indicated that $\mathrm{Cu}$ may cross the blood-brain barrier and regulate hormone secretion. Similar results were reported by Myres and Bowland (1973), who observed that pigs fed high $\mathrm{Cu}$ diets had larger loin cross-sections than those receiving no supplemental $\mathrm{Cu}$. Improved loin eye area suggests higher lean percentage and better carcass value. Further research is needed to better understand the effect of high $\mathrm{Cu}$ on improving loin muscle growth.

\section{IMPLICATION}

$\mathrm{Cu}(\mathrm{HMTBa})_{2}$ is more available based on performance and liver $\mathrm{Cu}$ concentration, so less $\mathrm{Cu}(\mathrm{HMTBa})_{2}$ is needed to have similar growth promoter effects as $\mathrm{CuSO}_{4}$ when fed to nursery pigs. For grower-finisher pigs, $80 \mathrm{mg} / \mathrm{kg}$ $\mathrm{Cu}(\mathrm{HMTBa})_{2}$ can be used as growth promoter and pigs fed $\mathrm{Cu}(\mathrm{HMTBa})_{2}$ had greater loin depth compared with 160 $\mathrm{mg} / \mathrm{kg} \mathrm{CuSO}_{4}$. By using less chelated $\mathrm{Cu}$ in pig diets, less $\mathrm{Cu}$ may be excreted to the environment although $\mathrm{Cu}$ concentration in feces was not analyzed in these trials.

\section{REFERENCES}

Ajuwon, O. R., O. M. O. Idowu, S. A. Afolabi, B. O. Kehinde, O. O. Oguntola, and K. O. Olatunbosun. 2011. The effects of dietary copper supplementation on oxidative and antioxidant systems in broiler chickens. Arch. Zootec. 60:275-282.

AOAC. 2000. Official methods of analysis (17th Ed). Association of Official Analytical Chemists. Arlington, VA.

Apgar, G. A., E. T. Kornegay, M. D. Lindemann, and D. R. Notter. 1995. Evaluation of copper sulfate and a copper lysine complex as growth promoters for weanling swine. J. Anim. Sci. 73:2640-2646.

Arias, V. J. and E. A. Koutsos. 2006. Effects of copper source and 
level on intestinal physiology and growth of broiler chickens. Poult. Sci. 85:999-1007.

Arnold, M. A. 2011. Interaction of copper source, bile composition on microbial growth, and $\mathrm{Cu}$ protein homeostasis. Master thesis. Colorado State Univ. Fort Collins, Colorado.

Banks, K. M., K. L. Thompson, J. K. Rush, and T. J. Applegate. 2004. Effects of copper source on phosphorus retention in broiler chicks and laying hens. Poult. Sci. 83:990-996.

Braude, R. 1967. Copper as a stimulant in pig feeding. World Rev. Anim. Prod. 3:69-82.

Bunch, R. J., V. C. Speer, V. W. Hays, and J. T. McCall. 1963. Effects of high levels of copper and chlortetracycline on performance of pigs. J. Anim. Sci. 22:56-60.

Bunch, R. J., V. C. Speer, V. W. Hays, J. H. Hawbaker, and D. V. Catron. 1961. Effects of copper sulfate, copper oxide and chlortetracycline on baby pig performance. J. Anim. Sci. 20:723-726.

Coffey, R. D., G. L. Cromwell, and H. J. Monegue. 1994. Efficacy of a copper-lysine complex as a growth promotant for weanling pigs. J. Anim. Sci. 72:2880-2886.

Cromwell, G. L., T. S. Stahly, and H. J. Monegue. 1989. Effects of source and level of copper on performance and liver copper stores in weanling pigs. J. Anim. Sci. 67:2996-3002.

Cromwell, G. L., V. W. Hays, and T. L. Clark. 1978. Effect of copper sulfate, copper sulfide and sodium sulfide on performance and copper stores of pigs. J. Anim. Sci. 46:692698.

Dove, C. R. and R. C. Ewan. 1991. Effect of vitamin E and copper on the vitamin $\mathrm{E}$ status and performance of growing pigs. J. Anim. Sci. 69:2516-2523.

FEDNA, 2003. Guidelines of the Spanish Foundation for Development of Animal Nutrition for the formulation of compound feeds (Ed. C. de Blas, P. Garcia, and G. G. Mateos). Madrid Polytechnical University, Spain.

Gipp, W. F., W. G. Pond, and E. F. Walker, Jr. 1973. Influence of diet composition and mode of copper administration on the response of growing-finishing swine to supplemental copper. J. Anim. Sci. 36:91-99.

Hall, A. C., B. W. Young, and I. Bremner. 1979. Intestinal metallothionein and the mutual antagonism between copper and zinc in the rat. J. Inorg. Biochem. 11:57-66.

Hawbaker, J. A., V. C. Speer, V. W. Hays, and D. V. Cantron. 1961. Effect of copper sulfate and other chemotherapeutics in growing swine rations. J. Anim. Sci. 20:163-167.

Kornegay, E. T. and A. F. Harper. 1997. Environmental nutrition: Nutrient management strategies to reduce nutrient excretion of swine. Prof. Anim. Sci. 13:99-111.

Marchetti, M., H. D. Ashmead, N. Tossani, S. Marchetti, and S. D. Ashmead. 2000. Comparison of the rates of vitamin degradation when mixed with metal sulphates or metal amino acid chelates. J. Food Composit. Anal. 13:875-884.

Manangi, M. K., T. Hampton, P. Fisher, J. D. Richards, M. Vazquez-Anon, and K. D. Christensen. 2010. Impact of feeding lower levels of chelated minerals vs. industry levels of inorganic trace minerals on broiler performance, yield, foot pad health, and litter minerals concentration. International Poultry Scientific Forum. Southern Poultry Science Society (SPSS) Annual Meeting and the Southern Conference on Avian Diseases Annual Meeting. Atlanta, GA, January 24-25, 2010.
Myres, A. W. and J. P. Bowland. 1973. Effects of environmental temperature and dietary copper on growth and lipid metabolism in pigs. Concentration and composition of plasma free fatty acids. Can. J. Anim. Sci. 53:127-132.

NRC. 1998. Nutrient requirements of swine 10th ed. National Academy Press. Washington, DC.

Richards, J. D., J. Zhao, R. J. Harrell, C. A. Atwell, and J. J. Dibner. 2010. Trace mineral nutrition in poultry and swine. Asian Australas. J. Anim. Sci. 23:1527-1534.

Roof, M. D. and D. C. Mahan. 1982. Effect of carbadox and various dietary copper levels for weanling swine. J. Anim. Sci. 55:1109-1117.

Shurson, G. C., P. K. Ku, G. L. Waxler, M. T. Yokoyama, and E. R. Miller. 1990. Physiological relationships between microbiological status and dietary copper levels in the pig. J. Anim. Sci. 68:1061-1071.

Tucker, M. R. 1997. Experiences with metal toxicities in North Carolina. Pages 97-100 in Proc. 40th Annual. Meet. Soil Sci. Soc. North Carolina, Raleigh.

Veum, T. L., M. S. Carlson, C. W. Wu, D. W. Bollinger, and M. R. Ellersieck. 2004. Copper proteinate in weanling pig diets for enhancing growth performance and reducing fecal copper excretion compared with copper sulfate. J. Anim. Sci. 82:10621070.

Wang, Z., S. Cerrate, C. Coto, F. Yan, and P. W. Waldroup. 2007. Evaluation of Mintrex copper as a source of copper in broiler diets. Int. J. Poult. Sci. 6:308-313.

Yi, G. F., C. A. Atwell, J. A. Hume, J. J. Dibner, C. D. Knight, and J. D. Richards. 2007. Determining the methionine activity of Mintrex organic trace minerals in broiler chicks by using radiolabel tracing or growth assay. Poult. Sci. 86:877-887.

Zhao, J., R. B. Shirley, M. Vazquez-Anon, J. J. Dibner, J. D. Richards, P. Fisher, T. Hampton, K. D. Christensen, J. P. Allard, and A. F. Giesen. 2010. Effects of chelated trace minerals on growth performance, breast meat yield and foot pad health in commercial meat broilers. J. Appl. Poult. Res. 19:365-372.

Zhao, J., R. J. Harrell, G. Allee, B. Hinson, P. Winkelbauer, C. Atwell, J. D. Richards, and M. Vazquez-Anon. 2009. Effect of an organic copper source on growth performance and tissue copper concentration in nursery pigs. Mid-west Animal Science Meeting. Des Moines, IA.

Zhao, J., R. B. Shirley, T. R. Hampton, J. D. Richards, R. J. Harrell, J. J. Dibner, C. D. Knight, M. Vazquez-Anon, and A. F. Giesen. 2008. Benefits of an organic trace mineral on performance with dietary $\mathrm{Cu}$ antagonism in broilers. Poult. Sci. 87:53(Abstr.).

Zhou, W., E. T. Kornegay, M. D. Lindemann, J. W. Swinkels, M. K. Welten, and E. A. Wong. 1994. Stimulation of growth by intravenous injection of copper in weanling pigs. J. Anim. Sci. 72: 2395-2403. 